\title{
Application of Tot'hema Eosin Sensitized Gelatin Film for Adaptive Microlenses
}

\author{
BRANKA D. MURIĆ, University of Belgrade, \\ Institute of Physics, Belgrade \\ DEJAN V. PANTELIĆ, University of Belgrade, \\ Institute of Physics, Belgrade \\ DARKO M. VASILJEVIĆ, University of Belgrade, \\ Institute of Physics, Belgrade \\ SVETLANA N. SAVIĆ-ŠEVIĆ, University of Belgrade, \\ Institute of Physics, Belgrade \\ BRANISLAV M. JELENKOVIĆ, University of Belgrade, \\ Institute of Physics, Belgrade
}

Original scientific paper

UDC: $617.7-76$

DOI: 10.5937/tehnikal706787M

In this paper we showed that tot'hema eosin sensitized gelatin (TESG) film can be used for adaptive microlenses fabriacation. The mechanical properties of a pure gelatin film were improved by adding tot'hema solution. We found that the elasticity of TESG film depend on the tot'hema concentration. By stretching the film, the microlenses were deformed uniaxially, and microlenses focal length can be tuned. The achieved microlenses focal lengths range from 0.05 to $0.2 \mathrm{~mm}$.

Key words: gelatin film, eosin, tot'hema, adaptive microlenses, optical properties, mechanical properties

\section{INTRODUCTION}

Optical lenses are widely used in science, industry, and daily life. Microlenses are lenses with dimensions smaller than $1 \mathrm{~mm}$. It can be used, either individually or as microlens arrays, in a various applications such as: wavefront sensors, medicine, quantum computer research and so on [1-7].

Direct laser writing, photolithography, and thermal reflow, as well as copying techniques such as hot embossing, and injection molding are various methods of microlens fabrication [8-14].

Various materials such as polymers, photosensitive glass, composites, and many other are used in the microlens fabrication[15-20].

Development of tunable lenses with variable focal lengths is very important for different applications. It can be used in eyeglasses for vision correction, zooming devices in photocameras and integrated in many

Author's address: Branka Murić, University of Belgrade, Institute of Physics, Belgrade, Pregrevica 118

e-mail: muric@ipb.ac.rs

Paper received: 01.12.2017.

Paper accepted: 08.12.2017. electrooptical systems. Also, adapive microlenses is significant for tunable photonic waveguides, miniature optical sensing, electronic display, and widezoom cell phone [21-24].

Today, in many cases is necessary to use adaptive microoptical devices, primarily microlenses. In most optical devices, microlenses have an important role in a focusing, imaging, detection, etc. Different variants of adaptive microlenses arrays were proposed [25, 26].

Gelatin is a biocompatible and biodegradable polymer extensively used in food, pharmaceutical, biophysics and biomedical fields. Poor mechanical properties of gelatin film can be improved by crosslinking with various chemical agents such as formaldehyde, epoxy compounds, genipin and glutaraldehyde (GTA) [27-29].

Previously, by modifying the gelatin with tot'hema solution, we improved the mechanical properties of the brittle film of pure gelatin. So we get a film based on gelatin doped with tot'hema and sensitized with eosin dye [30-33], (denoted as tot'hema-eosin sensitized gelatin, abbreviated as TESG.

The TESG film is easy to prepare, low cost nontoxic, and became stretchable by adding tot'hema 
solution. On the film microlenses can be formed by direct laser writing. Our main intention was to use TESG, as biocompatible, thermally stable, soft and elastic material, for tunable microlens fabrication. The microlenses with different diameter and depth were produced on a TESG layer using Nd:YAG laser light $\left(2^{\text {nd }}\right.$ harmonic wavelength of $532 \mathrm{~nm}$ ).

In this paper, TESG microlenses focal length tunability was obtained by applying controlled strain. The produced adaptive concave TESG microlenses (individual or microlens array) are suitable for numerous applications. Also, they can be copied onto polydimethylsiloxane (PDMS) and used as convex lenses. The shape change of TESG microlenses (and consequently the focal length) was reversibly changed as the applied strain is inside the elastic limit, that be presented in our future work.

\section{EXPERIMENTAL PROCEDURE}

\section{Film preparation}

All chemical components used for the film preparation are easily available, cheap and nontoxic. Tot'hema (Laboratoire Innotech International-France) - the trade name of a mixture of iron gluconate (equivalent to $50 \mathrm{mg}$ iron), manganese gluconate (equivalent to $1.33 \mathrm{mg}$ manganese), copper gluconate (equivalent to $0.7 \mathrm{mg}$ copper) and excipients. It is a drinkable solution frequently used to treat anemia.

The $100 \mathrm{ml}$ of $5 \%$ aqueous gelatin (Gelatin from bovine skin gel strength $\sim 225 \mathrm{~g}$ Bloom, Type B, Sigma) solution with $20 \%$ of sodium chloride (puriss, p.a. Sigma Aldrich) by weight of dry gelatin, and 0.3 $\mathrm{ml}$ of $1 \%$ aqueous eosin $\left(5 \mathrm{wt} . \%\right.$ in $\mathrm{H}_{2} \mathrm{O}$, Sigma Aldrich) solution was prepared as describred previously $[31,32]$. The five TESG solutions with different tot'hema concentrations $(5 \%, 10 \%, 15 \%, 20 \%$, and $30 \% \mathrm{v} / \mathrm{v}$ ) were made.

TESG film was prepared by the gravity-settling method pouring $2 \mathrm{ml}$ of TESG solution onto a leveled and cleaned microscope glasses slide covered with a very clean thermoplastic foil. The net result is a film, which is highly absorptive in the green part of the spectrum, permanently soft and elastic. Dried film can be easily removed from the foil. It can be peeled from one substrate and placed on another (plane or curved). The film was dumbbell-shaped specimens cut by the brass mold made according to the standards for elastic materials (ASTM D412).

\section{Microlens fabrication}

If TESG film irradiated with laser radiation in the green part of spectrum, (direct, focused or unfocused) laser beam produces lens like-dips. We have shown that concave microlenses can be produced by direct laser writing using second harmonic Nd:YAG laser (wavelength of $532 \mathrm{~nm}$ ). Microlens formation was followed by the creation of a diffraction picture on a diffuse screen, with millimeter scale, placed behind the film. This pattern was recorded by a CCD camera. The used experimental setup is shown in Figure 1. The laser power of $60 \mathrm{~mW}$ and exposure time of $20 \mathrm{~s}$ was used in experiment.

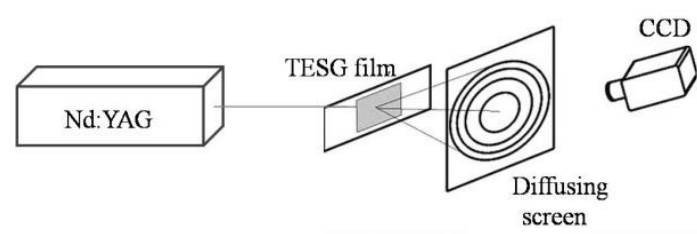

Figure 1 - Experimental setup for microlens fabrication

\section{Film thickness}

Film thickness was measured with a digital micrometer with $0.01 \mathrm{~mm}$ accuracy. Six thickness measurements were taken for each TESG film, and the averages were taken as the result.

\section{Water content of TESG film}

To estimate varying of water content during the film dehydration, the TESG films were weighed $\left(m_{w}\right)$, dried at ambient temperature $\left(20 \pm 2^{\circ} \mathrm{C}\right)$ for different time, and weighted $\left(m_{d}\right)$ again. Water content (or moisture content) was determined as the percentage of initial TESG film weight lost during drying and reported on a wet basis i.e:

$$
\% \text { moisture content }=100\left(m_{w}-m_{d}\right) / m_{w}
$$

Triplicate measurements of water content were done for each film, and an average was taken as the result.

\section{Swelling of TESG film}

TESG films were weighted in air-dried conditions $\left(W_{d}\right)$. Afterward, they were immersed in a physiological saline solution, containing $9 \mathrm{~g} / \mathrm{l}$ sodium chloride, for different time periods. Wet samples were wiped with filter paper to remove excess of liquid and reweighted $\left(W_{w}\right)$. The amount of adsorbed water was calculated:

$$
W(\%)=100\left(W_{w}-W_{d}\right) / W_{d}
$$

Stress-Strain Measurements

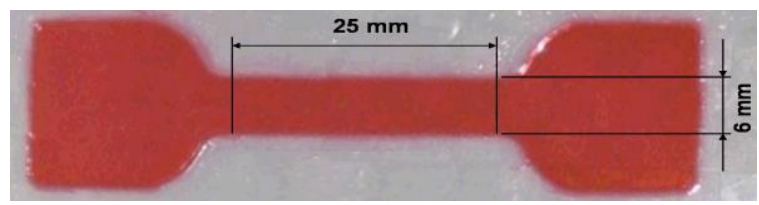

Figure 2 - TESG films used for tensile testing with dimensions according to the ASTM standards (gauge length $25 \mathrm{~mm}$, width $6 \mathrm{~mm}$ ) 
Stress-strain measurements of TESG films were determined in a tensile stress testing machine. Tests were carried out at $25{ }^{\circ} \mathrm{C}$ with a strain rate of 20 $\mathrm{mm} / \mathrm{min}$, using dumbbell-shaped film (see Figure 2) mounted at a specified gauge length $(25 \mathrm{~mm})$ into the system.

Using the appropriate software recorded force and corresponding displacement were recalculated into stress and strain.

The average value of five measurements for every film was calculated. The video camera was used to record the tensile responses of all films.

\section{SEM analysis of microlenses}

The morphology of produced TESG microlenses were investigated using a high resolution scanning electron microscope equipped with a high brightness Schottky field emission gun (FEGSEM).

\section{RESULTS AND DISCUSSIONS}

Variation of water content in TESG films with different tot'hema concentration with drying time is presented in Figure 3.

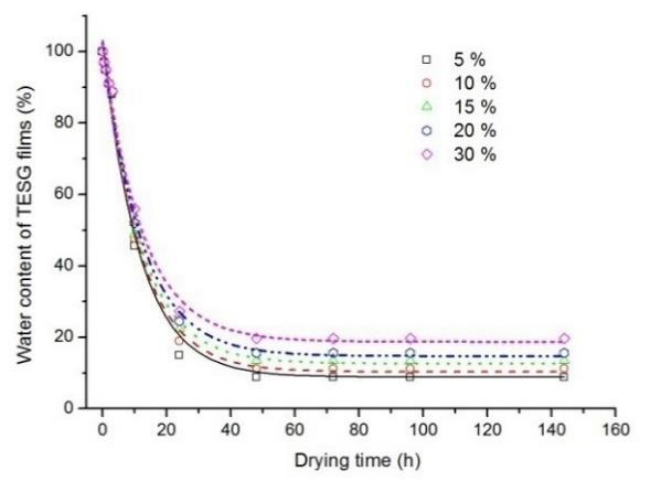

Figure 3 - Variation of water content of TESG films with drying time

It can be seen that the water content of each TESG films decreases with drying time up to 48 hour. After drying of two days, there is no additional change in the water content for all TESG films.

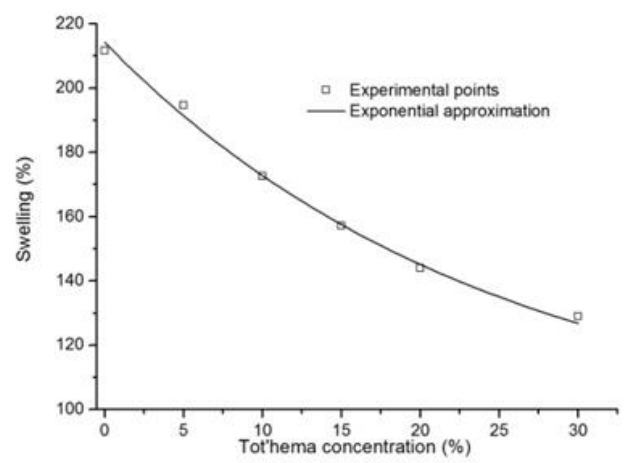

Figure 4-Swelling of gelatin films as a function of tot'hema concentrations
The degree of swelling of pure gelatin films stored in physiological solution increases up to about $220 \%$ after $24 \mathrm{~h}$. Tot'hema induces a reduction of swelling. From Figure 4 can be seen that swelling of TESG films exponentially decreases with increasing of tot'hema concentration. We found that swelling improve the fiIm elasticity.

During a laser irradiation, eosin bleaches, thus making TESG film colorless. In this case, as result of dye discolouration under the influence of optical radiation the transparent microlenses are formed, as can be seen in Figure 5.

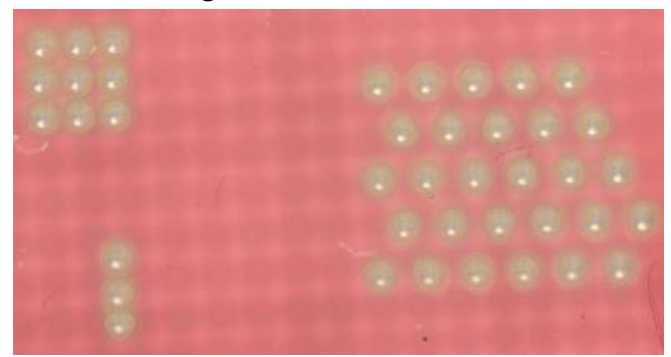

Figure 5 - Transparent $3 \times 3$ microlens array, and row of three microlenses (left) and hexagonal microlens array (right) on the TESG film

Figure 6 shows the stretching of microlens formed in the centre of a dumbbell-shaped TESG film.
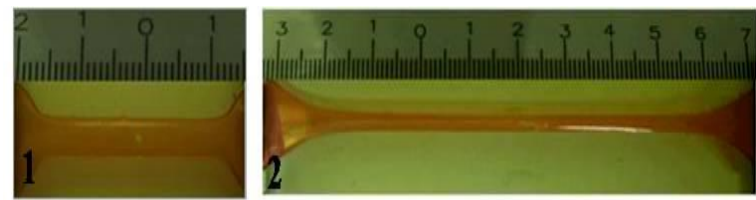

Figure 6 - The TESG microlens on the dumbbellshaped TESG film: 1) unstretched; and 2) stretched

The stretching value can be read on the ruler located parallel to film. It can be seen that TESG film stretched from the initial $25 \mathrm{~mm}$ to $80 \mathrm{~mm}$.

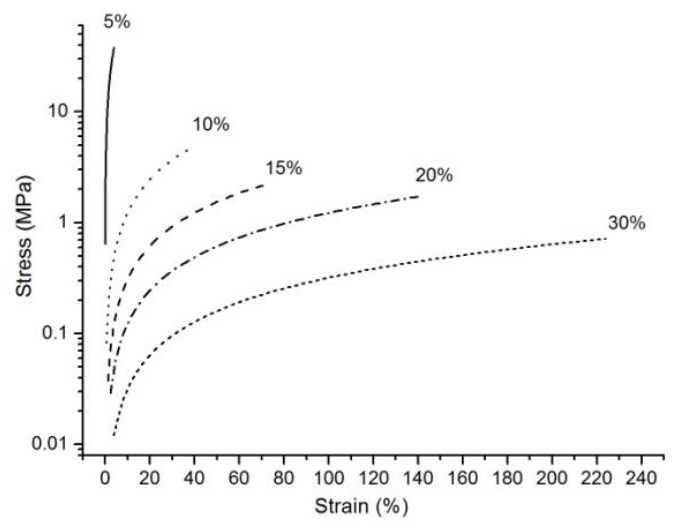

Figure 7 - Stress versus strain curves of TESG films

The results of uniaxial stress-strain measurements for all examined films are shown in Figure 7. The tensile responses of TESG films were measured up to the breaking point. As can be seen, mechanical 
properties of TESG films strongly depend on the tot'hema concentrations. The extensibility of the films increases, with increasing of tot'hema concentration up to $250 \%$.

The Young's modulus, the stress at break and the deformation at break of the films were calculated from the stress-strain curves. We found that Young's modulus and stress at break considerably decrease with increasing of tot'hema concentration.

Further we investigated the microlenses uniaxial stretching. Microlenses fabrication is followed by formation of diffraction picture on the diffuse screen. The recorded diffraction pictures extensions on a screen with a millimeter scale are shown in Figure 8.
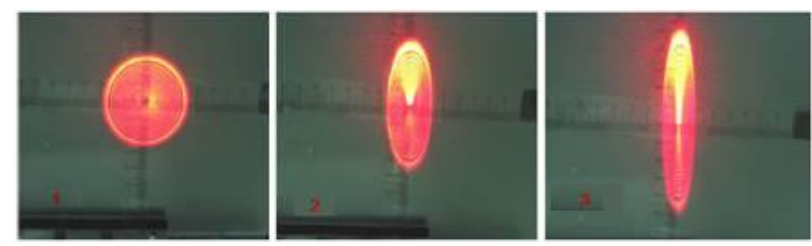

Figure 8-Diffraction picture recorded after the TESG microlens was: 1) formed; 2) and 3) stretched in one direction. Millimeter scale is visible.

The toric microlenses were produced due to the uniaxial strain. The astigmatic microlenses have two focal lengths along orthogonal directions. For uniform extension (along $\mathrm{x}$ and $\mathrm{y}$ direction) sphericity of microlenses can be retained.

It was shown that produced TESG microlenses change their optical properties, for example focal length, in response to material elasticity.

The relation between the focal length and strain is shown in Figure 9.

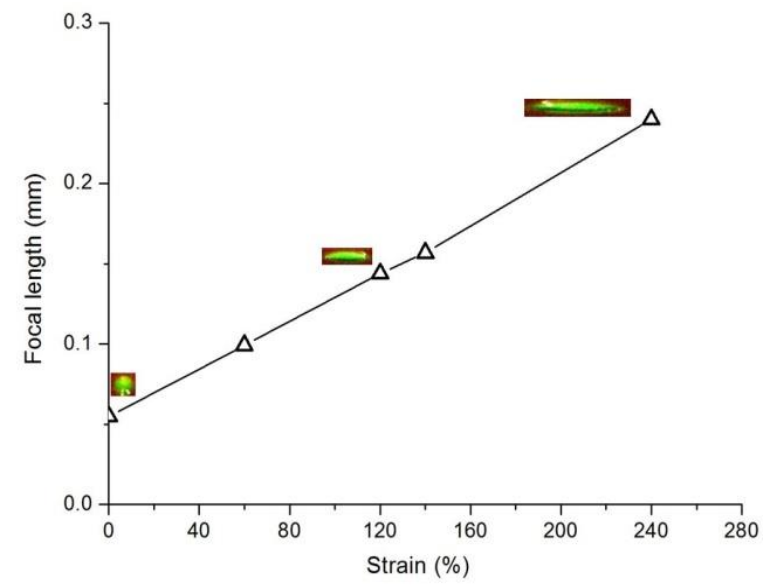

Figure 9-TESG microlens focal length versus strain

The microlens focal length exponentially increases with increasing strain of TESG film. The focal length was reversibly changed as long as the applied strain is inside the elastic limit. It was noticed that there is a linear dependence between the microlens focal length and diffraction pattern width (see Figure 10).

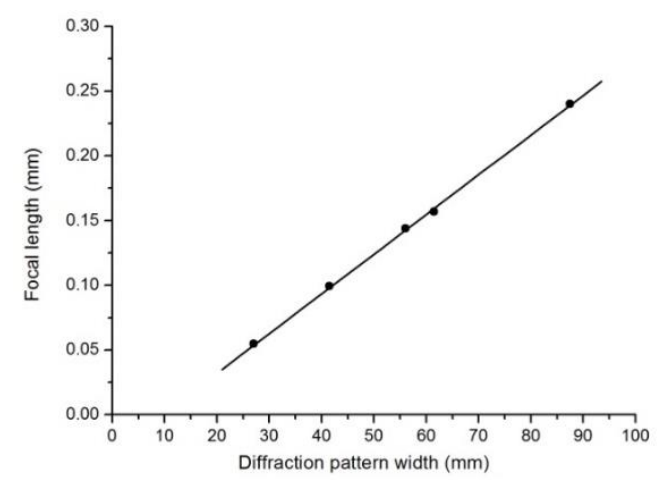

Figure 10 - TESG microlens focal length versus diffraction patern width

The strain responsive, transparent TESG microlenses offer interesting possibilities in tunable optical devices and sensors. Also, closely packed (hexagonal or square) microlenses arrays can be used to mimicking biological structure such as compound eyes. Hexagonal TESG microlenses arrays observed with an electron microscope is shown in Figure11.

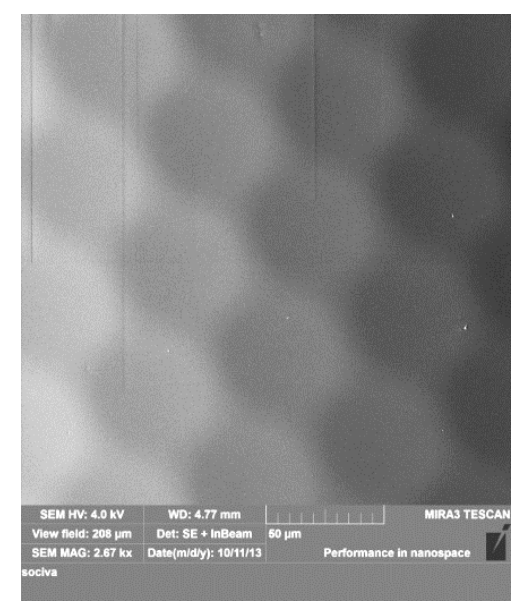

Figure 11 - Image of hexagonal TESG microlenses array is recorded using a field-emission gun scanning electron microscope (FEGSM)

Using of microlenses for visualization it is possible to obtain high-quality images. The picture of hexagonal TESG microlenses arrays with observed milimeter paper at its centre is shown in Figure 12.

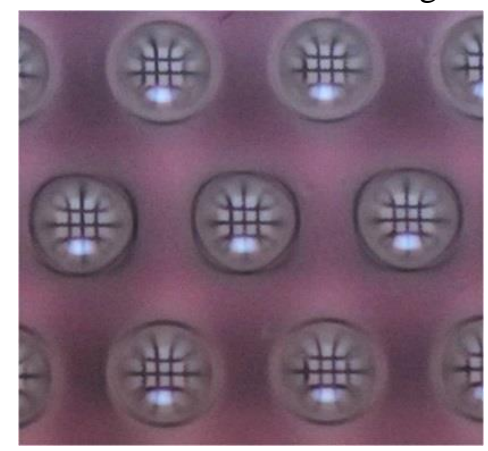

Figure 12 - Image of hexagonal TESG microlenses array recorded using an optical microscope 


\section{CONCLUSION}

Tunable (strain responsive) microlenses were prepared on elastic TESG film. Stretching the film of about $250 \%$, microlenses are uniaxial deformed so that the focal lengths were changed.The microlenses focal lengths from $0.05 \mathrm{~mm}$ to $0.2 \mathrm{~mm}$ were obtained. As TESG proved to be a good material for adaptive microlensess, we plan to retain sphericity of microlenses in the future and to achieve uniform stretching along both axes.

The TESG microlenses show good optical and imaging properties. The individual concave microlenses can be used. Also, the large-area square or hexagonal close-packed microlenses array can be used for various applications such as: medical laser, optical sensors, light-field cameras, biological structures. Convex microlenses can be produced by coping TESG lenses onto polydimethylsiloxane (PDMS).

\section{ACKNOWLEDGEMENT}

This paper was written as a part of research on the projects ON 171038 and III 45016 supported by the Ministry of Education, Science and Technological Development of the Republic of Serbia.

\section{REFERENCES}

[1] Liang W. L, Su G. D. J, Wide-angle and ultrathin camera module using a curved hexagonal microlens array and all spherical surfaces, Appl. Opt. Vol. 53, No 29, pp. H121-H128, 2014.

[2] Deng Z, Chen F, Yang Q, Bian H, Du G, Yong J, Shan C, Hou X, Dragonfly-eye-inspired artificial compound eyes with sophisticated imaging, $A d v$. Funct. Materials Vol 26, No 12, pp. 1995-2001, 2016.

[3] Zhang H, Li L, McCray D. L, Scheiding S, Naples N. J, Gebhardt A, Risse S, Eberhardt R, Yi A. Y, Development of a low cost high precision three-layer 3D artificial compound eye, Opt. Express Vol. 21, No 19, pp. 22232-22245, 2013.

[4] Zhang W, Zappe H, Seifert A, Wafer-scale fabricated thermo-pneumatically tunable microlenses, Light: Science \& Applications Vol. 3, pp. e145, 2014.

[5] Varshney A, Gohil S, Tadavani S. K, Yethiraj A, Bhattacharya S, Ghosh S, Large scale arrays of tunable microlenses, Lab Chip Vol. 4, pp. 1330-1335, 2014.

[6] Lu D. X, Zhang Y. L, Han D. D, Wang H, Xia H, Chen Q. D, Ding H, Sun H. B. J, Solvent-tunable PDMS microlens fabricated by femtosecond laser direct writing, Mater. Chem. C Vol. 3, pp. 17511756, 2015.

[7] Pavia J. M, Wolf M, Charbon E, Measurement and modeling of microlenses fabricated on single-photon avalanche diode arrays for fill factor recovery, $O p t$. Express Vol. 22, No 4, pp. 4202-4213, 2014.

[8] Sadasivuni K. K, Ponnamma D, Ko H. U, Zhai L, Kim H. C, Kim J, J, Electroactive and optically adaptive bionanocomposite for reconfigurable microlens, Phys. Chem. B Vol. 120, No 20, pp. 46994705, 2016.

[9] Kim S, Kang S, Replication qualities and optical properties of UV-moulded microlens arrays, J. Phys. D:Appl. Phys. Vol. 36, No 20, pp. 2451-2456, 2003.

[10]Naessens K, Ottevaere H, Baets R, Van Daele P, Thienpont $\mathrm{H}$, Direct writing of microlenses in polycarbonate with excimer laser ablation, Appl. Opt. Vol. 42, No 31, pp. 6349-6359, 2003.

[11]Wu M. H, Park C, Whitesides G. M, Fabrication of arrays of microlenses with controlled profiles using gray-scale microlens projection photolithography, Langmuir Vol. 18, No 18, pp. 9312-9318, 2002.

[12]Lee B. K, Kim D. S, Kwon T. H, Replication of microlens arrays by injection molding, Microsyst. Technol. Vol. 10, No 6-7, pp. 531-535, 2004.

[13]Ong N. S, Koh Y. H, Fu, Y. Q, Microlens array produced using hot embossing process, Microelectron. Eng. Vol. 60, No 3-4, pp. 365-379, 2002.

[14]PericetCamera R, Best A, Nett S. K, Gutmann J. S, Bonaccurso E, Arrays of microlenses with variable focal lengths fabricated by restructuring polymer surfaces with an ink-jet device, Opt. Express Vol. 15, No 15, pp. 9877-9882, 2007.

[15]Calixto S, Scholl M. S, Relief optical microelements fabricated with dichromated gelatin, Appl. Opt. Vol. 36, No 10, pp. 2101-2106,1997.

[16]Jones C. D, Serpe M. J, Shroeder L, Lyon L. A, Microlens formation in microgel/gold colloid composite materials via photothermal patterning, $J$. Am. Chem. Soc. Vol. 125, No 18, pp. 5292-5293, 2003.

[17]Jung H, Jeong Ki-H, Monolithic polymer microlens arrays with high numerical aperture and high packing density, ACS Appl. Mater. Interfaces Vol. 7, No 4, pp. 2160-2165, 2015.

[18]Wu M. H, Park C, Whitesides G. M, Fabrication of arrays of microlenses with controlled profiles using 
gray-scale microlens projection photolithography, Langmuir Vol. 18, No 24, pp. 9312-9318, 2002.

[19]Fu Y, Bryan N. K, Semiconductor microlenses fabricated by one-step focused ion beam direct writing, IEEE Trans.Semicond. Manuf. Vol. 15, No 2, pp. 229-231, 2002.

[20]He M, Yuan X. C, Ngo N. Q, Bu J, Tao S. H, Singlestep fabrication of a microlens array in sol-gel material by direct laser writing and its application in optical coupling, J. Opt. A: Pure Appl. Opt.Vol. 6, No 1, pp. 94-97, 2004.

[21]Peer A, Biswas R, Park J-M, Shinar R, Shinar Light management in perovskite solar cells and organic LEDs with microlens arrays, Opt. Express Vol. 25, No 9, pp. 10704-10709, 2017.

[22]Wrzesniewski E, Eom S.H, Cao W, Hammond W.T., Lee S, Douglas E.P, Xue J, Enhancing light extraction in top-emitting organic light-emitting devices using molded transparent polymer microlens arrays, Small Vol. 8, No 17, pp. 2647-2651, 2012.

[23]Tvingstedt K, Zilio S. Dal, Inganńs O, Tormen M, Trapping light with micro lenses in thin film organic photovoltaic cells, Opt. Express Vol. 16, No 26, pp.21608-21615, 2008.

[24]Chen Y, Elshobaki M, Ye Z, Park J.M, Noack M.A, Ho K. M, Chaudhary S, Microlens array induced light absorption enhancement in polymer solar cells, Phys. Chem. Chem. Phys. Vol.15, pp. 4297-4302, 2013.

[25]Song Y. M, Xie Y, Malyarchuk V, Xiao J, Jung I, Choi K.J, Liu Z, Park H, Lu C, Kim R. H, Li R, Crozier K. B, Huang Y, Rogers J. A, Digital cameras with designs inspired by the arthropod eye, Nature Vol. 497, pp. 95-99, 2013.
[26]Li Z, Xiao J, Mechanics and optics of stretchable elastomeric microlens array for artificial compound eye camera, J. Appl. Phys. Vol. 117, pp. 014904, 2015.

[27]Bigi A, Bracci B, Cojazzi G, Panzavolta S, Roveri N., Drawn gelatin films with improved mechanical properties, Biomaterials Vol.19, No 24, pp. 23352340, 1998.

[28]Bigi A, Cojazzi G, Panzavolta S, Roveri N, Rubini K, Mechanical and thermal properties of gelatin films at different degrees of glutaraldehyde crosslinking, Biomaterials Vol. 22, No 8, pp. 763-768, 2001.

[29]Bigi A, Cojazzi G, Panzavolta S, Roveri N, Rubini K, Stabilization of gelatin films by crosslinking with genipin, Biomaterials Vol. 23, No 24, pp. 4827 4832, 2002.

[30]Muric B. D, Pantelic D. V, Vasiljevic D. M, Panic B. M. Properties of microlenses produced on a layer of tot'hema and eosin sensitized gelatin, Appl. Opt. Vol. 46, No 35, pp. 8527-8532, 2007.

[31]Muric B, Pantelic D, Vasiljevic D, Panic B, Microlens fabrication on tot'hema sensitized gelatin, Opt. Mater. Vol. 30, No 7, pp. 1217-1220, 2008.

[32]Muric B, Pantelic D, Vasiljevic D, ZarkovB, Jelenkovic B, Pantovic S, Rosic M, Sensitized gelatin as a versatile biomaterial with tailored mechanical and optical properties, Phys. Scr. Vol. T157, pp. 014018, 2013.

[33]Muric B, Pantelic D, Vasiljevic D, Panic B, Jelenkovic B, Thermal analysis of microlens formation on a sensitized gelatin layer, Appl. Opt. Vol. 48, No 19, pp. 3854-3859, 2009.

\section{REZIME}

\section{PRIMENA FILMA ŽELATINA SENZIBILIZOVANOG TOT' HEMOM I EOZINOM ZA ADAPTIVNA MIKROSOČIVA}

U ovom radu smo pokazali da se film želatina dopiran tot'hemom i senzibilizovan eozinom (TESG) može koristiti za proizvodnju adaptivnih mikrosočiva. Mehaničke osobine čistog želatinskog filma poboljšane su dodavanjem rastvora tot'heme. Utvrdili smo da elastičnost TESGfilma zavisi od vrednosti koncentracije tot'heme. Istezanjem filma, mikrosočiva su deformisana duž jedne ose, pa se žižna daljina mikrosočiva može podešavati. Postignute vrednosti žižne daljine kreću se od 0.05 do $0.2 \mathrm{~mm}$.

Ključne reči: film želatina, eozin, tot'hema, adaptivna mikrosočiva, optičke osobine, mehaničke osobine 